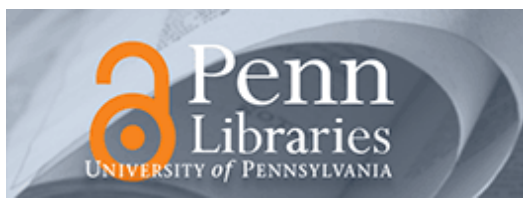

University of Pennsylvania ScholarlyCommons

Wharton Pension Research Council Working Papers

Wharton Pension Research Council

9-1-2009

\title{
Labor Market Uncertainty and Pension System Performance
}

Olivia S. Mitchell

The Wharton School, University of Pennsylvania, mitchelo@wharton.upenn.edu

John A. Turner

Pension Policy Center, jaturner49@aol.com

Follow this and additional works at: https://repository.upenn.edu/prc_papers

Part of the Economics Commons

Mitchell, Olivia S. and Turner, John A., "Labor Market Uncertainty and Pension System Performance" (2009). Wharton Pension Research Council Working Papers. 332.

https://repository.upenn.edu/prc_papers/332

This paper is posted at ScholarlyCommons. https://repository.upenn.edu/prc_papers/332

For more information, please contact repository@pobox.upenn.edu. 


\title{
Labor Market Uncertainty and Pension System Performance
}

\begin{abstract}
The financial market crisis has prompted policymakers to devote substantial attention to ways in which capital market risks shape pension performance, but few analysts have asked how shocks to human capital shape retirement wellbeing. Yet human capital risks due to fluctuations in labor earnings, employment volatility, and survival, can have a profound influence on pension accumulations and payouts. This paper reviews existing studies and offers a framework to think about how human capital risk can influence pension outcomes. We conclude with thoughts on how future analysts can better assess sensitivity of pension plan outcomes to a labor income uncertainty.
\end{abstract}

\section{Disciplines}

Economics 


\title{
Labor Market Uncertainty and Pension System Performance
}

\author{
Olivia S. Mitchell and John A. Turner
}

September 2009

\author{
PRC WP2009-11 \\ Pension Research Council Working Paper \\ Pension Research Council \\ The Wharton School, University of Pennsylvania \\ 3620 Locust Walk, 3000 SH-DH \\ Philadelphia, PA 19104-6302 \\ Tel: 215.898.7620 Fax: 215.573.3418 \\ Email:prc@wharton.upenn.edu \\ http://www.pensionresearchcouncil.org
}

\begin{abstract}
Mitchell is International Foundation of Employee Benefit Plans Professor of Insurance and Risk Management, the Executive Director of the Pension Research Council, and the Director of the Boettner Center on Pensions and Retirement Research at the Wharton School, University of Pennsylvania. Turner is Director of the Pension Policy Center. This paper was prepared for the World Bank/OECD/ING/BBVA/VB volume on Performance of Privately Managed Pension Funds. The authors acknowledge helpful comments from Karen Ferguson, Richard Hinz, and Heinz Rudolph. Opinions and conclusions are solely those of the author(s) and do not reflect views of the institutions supporting the research, with whom the authors are affiliated, or the Pension Research Council. Copyright 2009 (C) Pension Research Council of the Wharton School of the University of Pennsylvania. All rights reserved.
\end{abstract}




\title{
Labor Market Uncertainty and Pension System Performance
}

\author{
Olivia S. Mitchell and John A. Turner
}

\begin{abstract}
The financial market crisis has prompted policymakers to devote substantial attention to ways in which capital market risks shape pension performance, but few analysts have asked how shocks to human capital shape retirement wellbeing. Yet human capital risks due to fluctuations in labor earnings, employment volatility, and survival, can have a profound influence on pension accumulations and payouts. This paper reviews existing studies and offers a framework to think about how human capital risk can influence pension outcomes. We conclude with thoughts on how future analysts can better assess sensitivity of pension plan outcomes to a labor income uncertainty.
\end{abstract}

\section{Olivia S. Mitchell}

Pension Research Council, Dept of Insurance/Risk Management

The Wharton School, University of Pennsylvania

3000 SH-DH, 3620 Locust Walk

Philadelphia, PA 19104-6218

Phone: 215.746.5701 Fax: 215.898.0310

E-mail:mitchelo@wharton.upenn.edu

John A. Turner

Pension Policy Center

3713 Chesapeake St. NW

Washington, DC 20016-1813

Phone: 202-686-6775

Email: Jaturner49@aol.com 


\title{
Labor Market Uncertainty and Pension System Performance
}

\author{
Olivia S. Mitchell and John A. Turner
}

As perhaps never before, the financial market crisis is focusing attention on the many ways in which pensions are susceptible to capital market risks. And in keeping with the large magnitude of recent market collapses, many analysts have examined how equity risk translates into wealth and benefit payouts under alternative pension regimes. ${ }^{1}$ Nevertheless, relatively few analysts to date have explored how human capital risks are incorporated in pension system performance. The specific human capital risks on which we focus in this chapter include volatility in labor earnings and uncertainty in hours of work and the length of the worklife, as well as length of life after retirement. Thus, for instance, wage rates may rise or fall, hours of work may fluctuate, and at the extensive margin, the length of the worklife and the retirement period can vary when retirement ages or mortality patterns change. Each of these dimensions of labor market uncertainty involve different ways in which risk influences how workers earn a living and in turn, in how this risk is translated into risky retirement income.

In what follows, we discuss these issues as well as interactions between human capital and capital market risk that must also be accounted for in careful models of pension performance. We first briefly outline pension structures and how they interact with human capital risk. The discussion indicates which types of human capital risk have been captured (or ignored) in the literature to date, as well as what kinds of capital market risks are modeled. We then turn to a brief review of existing models and what they can teach us about the relative importance of human capital versus other types of risk. This is followed by a discussion of different ways to judge pension benefit outcomes, and we conclude with a discussion of what is needed to better integrate human capital risk when assessing pension performance.

\section{Pension Structures and Human Capital Uncertainty}

To introduce the topic, we briefly review key pension plan types and how different pension systems might interact with uncertainty in human capital resulting from volatility in wage rates and labor earnings, as well as changes in the length of the worklife and retirement period.

\section{Pension Plan Types}

Defined Contribution Plans. Defined contribution (DC) pensions are retirement programs where employer and employee contributions (in percentage or money terms) are explicitly deferred from workers'

\footnotetext{
${ }^{1}$ See for example, relevant papers in this volume including Antolin (2009), Musalem and Pasquini (2009), and Walker and Iglesias (2009).
} 
paychecks and accumulated in a retirement scheme. One prominent example is the $401(\mathrm{k})$ plan where US workers generally contribute a percentage of their pay, and where employers may also provide a match based on employee contributions. Similar systems include the Australian Superannuation program, the Chilean-style individual account system, and in private accounts under the Swedish funded DC scheme (Premium Pension), to name just a few.

In DC plans, pension accruals depend on how much and how often money is contributed to the plans. Since contributions usually depend on labor earnings, the accumulation of retirement assets is directly impacted by workers' earnings and employment patterns, as well as when they work. (Sometimes retirement assets are also made available for hardship withdrawals or loans, in which case benefit adequacy may be influence by the extent to which the option is exercised.) To dampen the impact of labor market volatility on retirement outcomes, DC schemes are sometimes paired with minimum benefit guarantees made available to workers who contribute a long time - as in the Chilean system prior to the 2008 reform, where workers had to contribute 20 years to earn a right to the minimum pension guarantee (Arenas de Mesa et al. 2008). In other cases, governments elect to subsidize contributions for those with low or no earnings, as in the case of the German Reister plans (Maurer and Schlag, 2003). In both instances, human capital risk in the form of shocks to employment, labor earnings, and pension contributions, will be mitigated by retirees receiving government support (particularly when the minimum benefit is financed with pay-as-you-go transfers outside the DC system). If such safety-net arrangements are not available, DC plans tend to provide relatively little protection for human capital risk. That is, a healthy and highly paid employee who always contributes to his plan is likely to end up with a much larger accumulation in his plan compared to a worker whose pay fluctuates, who experiences layoffs, and who may leave the labor force due to medical or other considerations.

DC plans also expose the worker to capital market risk and fiduciary risk. That is, participants often exert some degree of choice over where to invest their contributions, which exposes them to capital market risk arising from directly holding the underlying assets. The recent global financial meltdown illustrates how vulnerable retirement accounts may be to capital market shocks. ${ }^{2}$ Fiduciary risk refers to the opportunity for pension assets to be used for purposes other than intended, most recently illustrated by Argentina's government takeover of around $\$ 30$ billion in assets held by investors in the private pension system (Neumann 2008).

Defined Benefit Plans. There are many different types of defined benefit (DB) plans, but for the present purposes, they may be characterized as retirement schemes where promised benefits are described by formulas that depend on retiree lifetime labor earnings, years of service, and retirement ages. In many

\footnotetext{
${ }^{2}$ Pension accumulations in OECD countries dropped by an estimated $\$ 5$ trillion in 2008 due to the financial crisis (OECD 2008).
} 
Western nations, DB benefits are typically paid as a life annuity; in other countries, such as Japan, benefits are traditionally paid as a lump sum. DB plans treat human capital shocks differently than do DC plans. An employee with a DB plan must usually spend a certain number of years in the plan before he earns a so-called "vested right" or legal claim to an eventual retirement payment. Job change usually terminates or curtails a worker's eventual retirement entitlement, and even when it does not, the benefit is generally deferred until the plan's normal retirement age and may not be inflation-indexed. For this reason, DB plans can be quite risky for a mobile workforce: leaving a job with a DB plan or getting laid off or downsized prior to retirement can be financially costly to the affected worker. In this sense, the DC structure imposes fewer pension losses for those in high turnover jobs and industries, as compared to DB plans. It is also worth noting that DB benefit formulas can magnify labor market risk, to the extent that the benefit formula is linked to a worker's final pay. By contrast, DB formulas may use an averaging approach making the benefit a function of career average pay; this smooths labor earnings shocks in the payout levels.

Some argue that DB plans are safer than DC plans since participants need not bear capital market risk directly. This is thought to be true because the plan sponsor invests the plan assets and - in theory at least - boosts contributions if the plan becomes underfunded. Yet the apparent safety of DB plans is undermined when the plan sponsor fails to contribute and then goes out of business. As an example, when the Australian Ansett Airlines filed for bankruptcy in 2002 with an underfunded DB plan, participants experienced large pension losses as a result (Ferris 2005). In some countries (e.g UK, the U.S.), government agencies have been established to help protect against DB plan underfunding, but it is now clear that these schemes also face a substantial risk of insolvency (Brown 2008). In any event, DB plans can provide some protection against human capital risk, but they are far from being clearly 'safer' along many dimensions.

Hybrid Plans. Several variants on the traditional pension models incorporate both DB and DC aspects. ${ }^{3}$ Some are DB plans with DC-like features which shift risk traditionally borne by employers to workers by linking payout to market financial indexes. Others are DC plans with rate of return guarantees that seek to lower workers' exposure to financial market risks (Turner and Rajnes 2003). Some firms have hybrids that include both a DC plan and promise a DB floor benefit (Cohen and Fitzgerald 2007; McGill et al. 2009).

The Netherlands has its own version of hybrid pension called the 'collective defined contribution' (CDC) system (Bovenberg nd). Instead of basing benefits on final average earnings, the Dutch hybrid ties

\footnotetext{
${ }^{3}$ We also note that many workers have both DB and DC plans. In some countries, firms that offer separate DB and DC plans with no interaction between the two are deemed to be hybrid plans as for example, in Canada (Wesbroom and Reay 2005). About 14 percent of the U.S. private sector workforce participated in both DB and DC plans provided by their employer (Buessing and Soto 2006).
} 
benefits to career average earnings; benefit indexation depends on plan finances. A CDC plan has a benefit formula similar to a DB plan: that is, employers contribute a fixed percentage of wages to these plans and bear no additional liability if plan investments perform poorly. In turn, plan assets are managed by professional money managers but investment and longevity risks are shifted to employees as a group. When a CDC plan becomes underfunded, the plan governing body (formed by employer and employee representatives) must determine how to restore full funding. This can be achieved by increasing employee but not employer contributions, or by making benefit accruals and indexing contingent on plan financial performance. If the plan becomes overfunded, the workers generally benefit rather than the employer. Some Dutch companies have added the feature that if the plan becomes overfunded, they can reduce their contribution, but such plans do not qualify as a CDC plan. ${ }^{4}$

\section{Interactions between Human Capital Uncertainty and Pension Performance}

To dig deeper into how human capital uncertainty might affect payouts under different pension plan structures, this section takes up two conceptual issues. First we discuss how variability in labor earnings might translate into pension payouts under a DB plan, a CDC plan, and a DC plan. Second, we examine the same questions with regard to employment shocks. Table 1 summarizes the approach. The discussion is not exhaustive, but instead develops a typology of issues and highlight factors that must be taken into account in policy-relevant models of pension performance.

Table 1 here

Wage Shocks. Payoffs to human capital are reflected in the increment to wages and salaries paid to education, skills/training, and labor market experience. Because wage rates are not fixed over time nor over the life cycle, human capital risk involves uncertainty about the returns to these human capital investments. Wage shocks can arise for various reasons including skill obsolescence, productivity losses due to poor health or disability, or macroeconomic factors that alter the value of worker effort.

Longitudinal administrative records from employers or tax authorities are needed if one is to uncover patterns of pay over workers' lifetimes. Yet micro-level data on wage distributions are difficult to obtain, making it difficult to measure the magnitude and distribution of wage rate shocks and identify their root causes. As a result, most pension models assume a so-called "humped-shape earnings profile" for lifecycle earnings, taking the form of an inverted-U with age. Interestingly, this so-called 'classic' earnings pattern turns out not to be that commonplace, at least in some US where only 14 percent of US

\footnotetext{
${ }^{4}$ Some large plans have established pension "ladders," with formulas that explicitly determine the indexation rate applied to average wages and to benefits in payment at different plan funding levels. The adjustments tend to be made primarily through changes in indexation rates rather than through changes in contribution rates. These plans appeal to employers because the employer bears less risk than in a traditional DB plan. They can appeal to employees because the employee bears less risk than in a traditional DC plan.
} 
workers fit this profile (Bosworth et al. 1999). In that study about the same fraction had real earnings patterns that sagged during their middle years, another group had flat real earnings profiles, and still another had declining real earnings after some fairly young age. For instance Figure 1 shows the how mean earnings varies, depending on whether the average includes or excludes those with zero earnings, and how the percentage with zero earnings varies over the life cycle and by income bracket. This tantalizing evidence, though slim, suggests that the single hump-shaped lifecycle earnings profile is less than relevant for everyone.

Figure 1 here

Life-cycle earnings profiles also differ considerably by sex and income level. Table 2, from the same source, underscores this point. The same study showed that while one-quarter of US men had humpshape earnings profiles, only half as many women did. Half of all men had declining life-cycle earnings profiles, and one-third of the women. The data also show that low-earning women were most likely to have declining earnings profiles, but women were - somewhat surprisingly - also more likely to have rising earnings profiles than men. Another notable finding seen in Table 2 is that including only those with nonzero earnings produces higher and much smoother earnings patterns than would characterize workers as a whole. Including those who are unemployed or laid off changes thus results considerably, and the bias due to ignoring zero earning varies by sex, age, and income level. Whether these patterns are prevalent for other countries and cohorts is unknown, but it is first-order urgent to find out, so as to determine what "real world" labor patterns mean for "real world" retirement plan outcomes.

Table 2 here

Many analysts have worked on the question of why labor earnings differ across workers of different types and over the life cycle. Clearly health shocks and family patterns matter: in the UK, for instance women are more likely than men to work part-time and to interrupt their careers due to caregiving responsibilities; they also tend to retire earlier than men (Hermes 2009). Whether the volatility of labor income shocks also varies across people over the life cycle is less well-studied. Mazumder (2001), for instance, uses administrative records to show that the variance in the transitory component of earnings in the US follows a U-shaped pattern with age and groups such as Blacks and the less-educated have higher lifetime earnings variances than others. While more remains to be shown along these lines, the patterns imply that projections of pension replacement rates which assume everyone traces out a smooth earnings profile are inaccurate for many. As an example, Mitchell and Phillips (2006) use US data to show that benefit replacement rates generated for actual workers' career paths tend to be much higher than for simulated hypothetical lifetime earners. ${ }^{5}$ This occurs because actual pay profiles are more

\footnotetext{
${ }^{5}$ Others working with actual earnings trajectories include Mitchell et al. (2007), Mitchell et al. (2000), and Nichols and Favreault (2008).
} 
erratic and lower than commonly-used hypothetical profiles; since the benefit formula is more generous to low-lifetime-earners, benefit replacement rates are therefore higher than usually simulated.

Another factor to note is that shocks to labor earnings may translate differently into retirement incomes, depending on whether the pension regime is DB, DC, or hybrid. Also important are specific plan features, which often include notches or nonlinearities which can dramatically change outcomes with just one more year of work, for instance. As Table 1 indicates, normally pension benefits depend in some way on lifetime earnings, but in a DC plan, each year of earnings matters for pension outcomes because contributions are deposited annually. Moreover, early years tend to matter the most, when compound interest is earned on assets. By contrast, career-average DB plans tend to weight each year of pay similarly, while final-pay formulas count only the last (or last few) years in computing benefit amounts. For this reason, wage shocks occurring late in life tend to have a larger impact on benefit outcomes in DB than in DC plans. Using UK parameters, Blake et al. (2007) conclude that DC plans are most attractive to workers with highest career average salaries (relative to final salary), as well as those whose salary peaks early in their careers. Assuming the same constant contribution rate, male personal service workers in that model receive 34 percent higher DC pensions (relative to final salary) than male professionals whose incomes peaked later in their careers. DB plans, by contrast, favor workers with high earnings at the end of their careers, long-tenured and persistently high achievers.

Employment Shocks. Next we discuss how pension systems might differ in the way they transmit employment shocks into pension outcomes, a matter of particular concern when labor markets are very fluid and/or workers flow in and out of formal sector employment. This is particularly relevant in developing countries with relatively few pension-covered jobs but many pension-uncovered jobs. ${ }^{6}$ In Mexico, for instance, there are substantial flows between employment and self-employment; in the latter case, the worker is unlikely to contribute to the pension (Bosch and Maloney 2006). In the Chilean individual accounts system, a large fraction of workers is only intermittently attached to the pension system, in part because their jobs are short-term, in part because they are self-employed and not required to contribute, and in part because of contribution evasion (Figure 2, c.f. Arenas de Mesa et al. 2008). In this case, projected replacement rates which assume a full career of contribution will substantially overestimate retirement payouts. Moreover, the bias again differs by subgroups; for instance, Arenas de Mesa et al. (2008) show that those with the highest 'density of contributions' (or fraction of the worklife during which positive contributions are made) are the better-paid, better educated, and male employees.

\footnotetext{
${ }^{6}$ Another problem arising from volatile employment patterns is that workers may lose their pension entitlement due to poor documentation, or because the plan sponsor may have changed location, changed names, been bought out or merged with another firm, or gone out of business. This occurs in both DB and DC plans but is more prevalent in DB plans because they are less likely to provide portability (Bruce et al. 2005). Because of these changes, workers may encounter difficulties finding their pension plans to claim benefits.
} 
Conversely, those least likely to have persistent pension coverage are women and the less educated. Contribution evasion is also common in developing nations, particularly for small firms and among lower paid employees (Bailey and Turner 2001).

Figure 2 here

Pension systems also differ in the way they handle employment volatility, with few schemes offering perfect "pension portability" preserving employee rights to retain pension rights after leaving a job. In the DB context, job changers and those with weak labor market attachment may lose for two reasons. First, they may never gain eligibility for a benefit: for instance, the U.S. Social Security system requires a minimum of 10 years of contributions to receive any retirement pension. Second, DB backloading rules mean that mobile workers give up the option for rapid benefit accruals just prior to retirement. In Canada, for instance, a terminated worker's DB benefit is normally fixed in nominal terms, so as soon as the worker leaves his firm, his deferred pension payment immediately begins to fall in value due to inflation. Job changers may also suffer a DB benefit loss because they give up early retirement subsidies; see McGill et al. (2009). ${ }^{7}$ The DC model is generally more forgiving of job change, though there can still be problems due to vesting rules.

Another factor that has not much been noted in models of pension performance to date is the role of macroeconomic shocks. Recessions can have an important impact on pension accruals, inasmuch as economic downturns wreak job destruction, erode job creation processes, and generate high levels of involuntary turnover. As an example, in the U.S., more than one-fifth of 401(k) participants reduced their contributions and 4 percent stopped contributing in 2008 due to the economic downturn (O'Connor-Grant 2008). In Uruguay, Bucheli et al. (2007) report an average contribution density of 60 percent over the lifetime, an average that conceals wide extremes, with 28 percent contributing in all months, and another 40 percent contributing less than half the time. For the present purposes, the most interesting finding was that the contribution density was closely linked to the unemployment rate, falling when unemployment was high and rising when it was low. The Uruguay study also reports that contributions for higher-paid

\footnotetext{
${ }^{7}$ Efforts to link life cycle employment volatility and pension outcomes are few, mainly because of the difficulty of obtaining microeconomic longitudinal data on the patterns of real workers' contributions to their pension schemes. In the U.S., the evidence suggests that DC plan participants are persistent in making contributions, but the contribution rates vary over time. Thus Smith et al. (2004) followed employees in 401(k) plans for a dozen years, and reported that only 27 percent of those studied made persistent contributions at a stable contribution rate for the entire period. Of the remainder, 24 percent increased their contribution rates over time, 8 percent decreased their payments, 19 percent had breaks in their contribution patterns, and 23 percent had fluctuating contributions. Using tax data 1987-96, Smith (2001) found substantial dropoff rates in workers' contributions to Individual Retirement Accounts (IRAs); only 45 percent were still contributing in 1992, and 40 percent contributing through 1996, of those who contributed in 1987. In the UK context, Smith (2006) found a link between pension contributions and changes in income needs measured by changes in financial circumstances such as health shocks, having a baby, or moving to a new house. In Canada, about half of participants in Registered Retirement Savings Plans (RRSPs, or individual account plans) contributed in only one or two of the three years between 1991 and 1993 (Maser 1995).
} 
employees declined during economic downturns because people lost their jobs, moved to the informal sector, and had greater difficulty finding formal sector jobs; the pattern did not hold for the low-paid, or for workers in the public sector. In Chile, higher national unemployment rates have been found to depress contribution densities for men but have the opposite effect on women, perhaps because women offset labor market changes experienced by their husbands (Berstein et al. 2005).

Pension Payouts. Above we identified several ways in which human capital risk influences pension accumulations; it is also worth mentioning how these same factors can influence payouts. This can occur with pre-retirement withdrawals, permitted in countries such as Canada, where LeBlanc (2002) shows that people facing substantial reductions in labor income accounted for most of the pre-retirement pension withdrawals. ${ }^{8}$ Pension outcomes can also respond to employment via retirement behavior. How long people work and when they retire also shape both pension accumulations and the level of benefits paid during retirement. This is particularly true for DB plans, since many countries' national DB systems heavily subsidize early retirement benefits (Gruber and Wise 2007) and these subsidies have induced early retirement. The linkage tends to be exacerbated in recessions when older workers may view the pension as a subsidized way to leave the labor market rather than remain unemployed.

By contrast, it is sometimes argued that DC plans have no effect on retirement decisions: that is, if payouts are actuarially neutral, there may be economic benefit or penalty from deferring retirement an additional year. But several plan design elements can inhibit actuarial neutrality. For instance, a DC plan may sometimes be priced using outdated or unisex mortality tables, making expected benefits for any given individual actuarially unfair (Horneff et al. 2009); here the DC plan still can influence retirement patterns. Also if DC accounts earn unexpectedly negative investment returns, wealth effects are likely to induce workers to delay retirement to offset pension losses (Gustman and Steinmeier 2002). This is likely to be important in the current financial climate. Relatedly, those wishing to annuitize their account balances will tend to delay retirement when interest rates fall due to reduced annuity payments (Soares and Warshawsky 2003). ${ }^{9}$

In sum, this section has shown that DB participants face the problem of lack of portability when changing jobs, as well as uncertainty about how shocks to labor income will influence benefit payments. They are also exposed to the potential of DB plan termination or bankruptcy, about which we say more below. In DC plans, workers may experience labor or capital market shocks which leave them with periods of low or non-contribution and/or unexpectedly low benefit amounts.

\footnotetext{
${ }^{8}$ In other countries, pre-retirement access to pension funds by workers is not permitted.

${ }^{9}$ Burtless (2000), for example, evaluates the impact of fluctuations in financial markets using U.S. historical data for a hypothetical worker in a DC plan; the author concludes that variations in capital returns and the discount rate for an annuity conversion can change the value of retirement income relative to pre-retirement earnings by 20-110 percent of pre-retirement earnings. For workers with a DB plan, the employer bears the risk of fluctuation in the underlying assets, whereas in hybrid CDC plans, this risk is shared between employers and employees.
} 


\section{Integrating Human Capital Uncertainty into Models of Pension Outcomes}

Next we turn to an overview of models that have been developed to illustrate the importance of human capital risks for pension outcomes. Our discussion outlines how these models differ according to their structure, inputs, outputs, and solution methods, seeking to illustrate the strengths and weaknesses of different approaches for different purposes. In what follows, we first differentiate between deterministic versus stochastic models, noting that deterministic models can be run using alternative scenarios as a way of exploring the range of outcomes. Next we discuss microeconomic optimization models used to study the optimal structure of retirement income systems. We conclude with a discussion of how to integrate human capital and capital market interactions. Table 3 summarizes key findings.

\section{Table 3 here}

Alternative Modeling Approaches. Models of pension system can be used to simulate alternative outcomes, often for the purpose of assessing reform options. The building blocks of typical models include labor market patterns - including labor earnings, job change, un/nonemployment, and retirement patterns - and capital market outcomes - namely the risk and return assumptions pertinent to assets held (in the case of a funded system). In addition, specific pension system behaviors may need to be modeled to determine pension contribution patterns, investment allocations, and, possibly, leakages from these accounts.

Deterministic vs Stochastic Models. To reduce the complexity of the problem, many analysts have taken a deterministic tack, rather than explicitly modeling shocks to human and financial capital. One such approach uses simulation: for instance the World Bank's Prost model is a nonstochastic aggregate approach used by many countries to make aggregate projections of their pension system financial flows.

${ }^{10}$ Prost models pension contributions, entitlements, system revenues and system expenditures over a long time frame. As another recent example, Munnell et al. (2006) project DC plan account balances of workers to age 65 (assuming all retire at that age) based on current age/cohort patterns in the US Survey of Consumer Finances. Thus capital market risk and human capital risk are explicitly ignored and they preserve observed current differences in wealth accumulation over time. The authors also assume all households annuitize their total wealth at retirement (including housing wealth) using an inflation-indexed annuity with a two-thirds survivors benefit. This approach is critiqued by Scholz et al. (2008) as understating retirement replacement rates because it uses a single projected earnings trajectory; it thus overstates future earnings for many people. Other analysts simplify the projection problem in other ways,

\footnotetext{
${ }^{10}$ In a few instances, aggregate models have been expanded to incorporate some stochastic features; for instance Burdick and Manchester (2003) use MINT to examine Social Security system finances in the US, and Van Rooij et al. (2005) uses the PALMNET model to evaluate the future status of pension plans in the Netherlands.
} 
for instance assuming that invested pension assets earn a constant rate of return over time in projecting DC plan accumulations (c.f. Poterba et al. 2007; Mitchell et al. 2000). ${ }^{11}$ Researchers have often had to rely on aggregate data and actuarial models to compute benefit replacement rates for hypothetical fulltime workers employed over their entire careers (Mitchell 2008). Such a "cell-based" approach uses stylized earnings paths, such as those used in OECD (2007) and Whitehouse (2007) derived from average economy-wide earnings paths, on the assumption that these hypothetical workers never change their relative position in the earnings distribution and further that there is no volatility in earnings profiles. Related work for Peru by Bernal et al. (2008) employs aggregate coverage data in an actuarial cell-based model to predict eventual replacement rates; similar simulations for Chile appear in Berstein et al. (2005) and Favre et al. (2006).

An alternative approach for generating pension outcomes employs stochastic simulation to estimate the range of outcomes that might be associated with factors such as longevity, capital market performance, or labor income uncertainty. Following Orcutt (1957), microsimulation models are widely used by policymakers in many nations to project retirement income adequacy with computer models that model individual units, such as people or firms, in a complex system of multiple equations. ${ }^{12}$ In such an approach, one or more of the projection factors is assigned a random rather than a fixed value. Each simulation makes random draws for the stochastic variables from their assumed probability distributions and uses those values to produce future pension outcomes. Those outcomes are assumed to represent the distribution of actual outcomes that might be realized in the future. Multiple runs produce an array of results which can then be analyzed statistically, including calculating the probability and size of shortfalls.

A recent criticism of these models is that they usually assume a normal distribution for stock market returns, but it may be that the probability of extreme events is higher than that represented by a normal distribution (called the "fat tails" problem; see Laise 2009). Researchers have not yet addressed whether the distribution of human capital risks also are exposed to this sort of non-normal risk.

The choice of which approach to use depends to some extent on the data inputs available, and the questions driving the analysis. For instance, Kotlikoff (2008) treats mortality and stock market rates of return as stochastic, and examines the impact of insurance on individuals' retirement saving patterns; his

\footnotetext{
${ }^{11}$ For instance, Poterba et al. (2007) do not model capital market risk in making their projections. Rather, they assume that $401(\mathrm{k})$ portfolios are allocated $60 / 40$ to large capitalization equities/corporate bonds; that the average returns on corporate equities is equivalent to about 9.2 percent real and 3.2 percent on bonds. Further, they omit any impact of investment fees on net rates of return. They report average (mean) account balances. Given the skewness in account balances, with a small number of people having large balances, median account balances would be more indicative of the account balances of the typical participant. Account balances at the bottom and top decile would provide information about the extremes. They do not report replacement rates, but calculate the ratio of total 401(k) assets to GDP.

${ }^{12}$ Surveys of this literature include Baroni and Richiardi (2007) and Dupont et al. (2003); examples of software include Destinie (Crenner 2008) for France, Cosi and Midas (Dekkers et al. 2009) in Belgium, and Pensim (Curry 1996) in the United Kingdom.
} 
study does not account for human capital risk other than longevity. Other analysts have devoted years to building microsimulation models that do take into account both human capital and capital market risk: models include the Social Secuirity Administration's MINT model (Modeling Income in the Near Term, Sarney 2008); the Urban Institute's DYNASIM model (Dynamic Simulation of Income Model; Butrica et al. 2008); the Labor Department's PENSIM (Pension Simulation model; Holmer 2006), the Congressional Budget Office's Long-Term model (Sabelhaus 2008); the EBRI-ICI 401(k) Accumulation Projection model (Holden and VanDerhei 2002a, b); and a new model under development at the Investment Company Institute (Sabelhaus and Brady 2008). ${ }^{13}$

Microeconomic Optimization Models. An alternative to simulation/projection models is to devise life cycle economic optimization models that generate desired wealth distributions in retirement. These desirable outcomes can then be compared to actual wealth patterns, to determine whether substantial shortfalls exist. Recent work by Sholz and coauthors arrives at the controversial conclusion that, at least in the US, much of the population has saved adequately for retirement (Scholz et al. 2006; Scholz and Seshadri, 2008). That model necessarily embodies key simplifications: for instance, the authors assume

\footnotetext{
${ }^{13}$ Both the MINT model and the ICI model are mainly used for pension policy outcomes analysis. The MINT model matches Social Security earnings records to data from the Census Bureau's Survey of Income and Program Participation (SIPP). Both the ICI model and DYNASIM can be used to study distributional issues and aggregate policy costs and effects. The new ICI model is similar to PENSIM in its focus on how job changes affect pension outcomes (Sabelhaus and Brady 2008). Holden and VanDerhei (2002a, 2002b) use the EBRI-ICI 401(k) Accumulation Projection model to project the proportion of pre-retirement income that will be replaced by $401(\mathrm{k})$ assets. They incorporate uncertainty by each year determining whether a person contributes based on the percentage of workers at his age, tenure and salary level that participate. Similarly, a probability is assigned to determine whether a participant would take a loan or a pre-retirement withdrawal from his $401(\mathrm{k})$ plan. Loans and preretirement withdrawals are not allowed in most countries. Each year in the projections, rates of return are randomly assigned from the historic range of rates of return for different asset classes. In addition, they investigate the effects of capital market risk by running different scenarios in which they limit the range of rates of return to simulate a worst case scenario, or the effects of timing of a brief bear or bull market at different points of a worker's career or retirement. The Congressional Budget Office $(2004 \mathrm{a}, \mathrm{b})$ projects asset flows into and out of DB, DC, and IRA plans. The studies assume that future participation and contribution rates will equal the age-specific rates in 1997 . These studies do not consider the future spread of 401(k) plans or the effects of demographic trends on the accumulation in personal retirement plans. Poterba et al. (2007) project future levels of U.S. 401(k) account balances as of age 65 for cohorts for the years between 2000 and 2040. Those authors note that projected account balances depend critically on assumed rates of return: if one assumes the historical average, average account balances are projected to amount to about $\$ 452,000$ (in 2000 dollars); however if the historical average less 300 basis points is assumed, averages will only be $\$ 269,000$. To derive these estimates requires a large number of assumptions. Worker earnings are projected using the Health and Retirement Study. The intermediate earnings growth rate is used from the 2005 Annual Report of the Trustees of the Social Security Administration. Pension participation rates, job separation rates, and taking lump sum distributions at job separation are aspects of human capital risk or of behavior that they consider. Job separation rates are based on the 1998 Survey of Income and Participation (SIPP) based on five-year age intervals. Separation rates vary by age but not by time on the job. SIPP data from various years are used to track the spread of 401(k) plans and to project future participation rates. Based on this data, they assume the future annual rate of increase in $401(\mathrm{k})$ participation rates declines by 0.12 percent per year. The probability that the worker takes a lump sum distribution given job separation is taken from the Health and Retirement Survey. Based on data from the 2003 Survey of Income and Program Participation (SIPP), a combined employer-employee contribution rate of 10 percent is assumed, which does not vary across workers or over time.
} 
that households face no mortality risk and pay no out-of-pocket health care expenses prior to retirement, and workers' pay is subject to a common random shock correlated across time. Uncertainty in retirement arises from post-retirement mortality and health care expenditures, the latter of which are also correlated over time. The authors assume that employees earn a constant real rate of return of 4 percent for both stocks and bonds, so capital market risk is ignored. The paper argues that older couples following an optimal consumption path will reduce consumption by one-third after the children leave home, and by another 30 percent after the death of one spouse. Taking account of household composition changes, they argue that far lower saving rates are needed than usually recommended by simple projection models and financial advisers; overall, they authors conclude that most U.S. households have saved optimally for retirement. It must be noted that the simulations take as given current Social Security benefit offerings, which in fact may be too optimistic given the system's pending insolvency; they also take mortality patterns as given. To the best of our knowledge, no one has applied this methodology to other countries.

In recent years, it has become increasingly feasible to use dynamic optimization to solve microeconomic life cycle models to determine how sensitive retirement outcomes might be to changes in underlying parameters. Some analysts use an illustrative individual assumed to start working early in life, accumulate retirement assets, and spend these funds to support retirement consumption (c.f. Horneff et al. 2007a,b, 2009). Such studies generally assume that the equity returns follow a random walk process with log normal returns, given some pre-specified mean and standard deviation. These models posit that individuals smooth their expected marginal utilities of consumption by selecting optimal consumption, saving, investment, and decumulation profiles. Early versions of this methodology assumed no uncertainty and adopted set values for future wage growth, returns on pension investments, and lifespans. ${ }^{14}$ The advent of more computational power has permitted analysts to integrate ever more complexity, including stochastic mortality, risky equity returns, and most recently, risky labor earnings (c.f. Horneff et al. 2009; Maurer et al. 2009a). This approach generally solves for a household's optimal portfolio mix rather than evaluating what an optimal replacement rate might be, as this approach focuses on investment questions and utility maximization rather any particular replacement rate outcome.

As one example, Campbell et al. (1999) showed that, the riskier is a person's labor income, and the more highly this risk is correlated with capital market volatility, the less she will tend to invest in equities. In this framework, labor income is cast as a non-tradable asset that affects the portfolio allocation of other assets in the worker's optimal portfolio. To the extent that human capital return profile has bond-like characteristics, this model implies that people with more human capital should favor equity in their pension accounts, particularly early in their careers (Blake et al. 2007). Horneff et al. (2009) extend the model by showing how human capital and capital market risks influence portfolio choice over

\footnotetext{
${ }^{14}$ Horneff et al. (2007a,b) review this rapidly expanding literature.
} 
the life cycle, particularly focusing on what happens when retirees can purchase payout annuities. That study shows that investors will optimally hold a high fraction of equities while young, with the fraction in equity falling with age. Further, they will move money from liquid saving into annuities as they approach retirement and continue to do so until the late $70 \mathrm{~s} .{ }^{15}$ Thus models indicate that risky human capital interacts with capital market uncertainty to importantly shape investment decisions.

The next step in the research arena is to show how interactions between capital market shocks, labor income uncertainty, and retirement outcomes affect portfolios. Some researchers have modeled how work hours over the life cycle might react to volatility in equity returns, but many assume, rather unrealistically, that labor income risk is fully insurable in the capital market (i.e. wages are perfectly correlated with traded risky securities). ${ }^{16}$ A few authors, most notably Gomes et al. (2008), do take the next step by examining how workers might adapt their hours in response to shocks; to simplify the modeling, this study assumes mandatory retirement at a fixed age. In the real world of course, longer worklives also offer an important way in which older workers can adjust to negative labor and capital market surprises. Chai et al. (2009) take the next step by showing that, when both hours of work and retirement ages are endogenous, people boost their optimal equity holdings, particularly at older ages. Younger people also work more, and introducing annuities prompts earlier retirement and higher participation by the elderly in financial markets

There is surprisingly little evidence on how correlations between shocks to labor income and capital market returns might drive retirement behavior. Indeed the most cited study assumes a zero correlation between stock returns and labor income shocks, relying on a US longitudinal study to justify this parameterization (Cocco, Gomes, and Maenhout 2005). More recently, models incorporating human capital risk in pension outcomes are emerging which allow correlations between labor earnings and capital market uncertainty (Viceira 2009; Bagliano et al. 2009). In general, when labor income uncertainty is correlated with equity return shocks, this will powerfully alter workers' investment portfolios and work patterns.) Maurer et al. (2009a) show that more labor income uncertainty, or reduced old-age benefits, boosts demand for stable income for both the young and retirees. In addition, a declining equity glide path with age is appropriate for workers having little labor income uncertainty; by contrast, a worker anticipating high income risk, equity exposure starts low and rises to retirement age. In related work, Chai et al. (2009) conclude that higher labor income uncertainty spurs demand for stable income

\footnotetext{
${ }^{15}$ When annuities are fairly priced, that study shows that a 40 -year old investor lacking any bequest motive would trade half of her liquid wealth to gain access to the annuity; with a moderate bequest motive, she would still exchange one-third of her wealth to gain access to annuities. When reasonable loads and asymmetric mortality distributions are included, the utility gains are still worth over one-third of financial wealth.

${ }^{16}$ See the studies reviewed in Chai et al (2009).
} 
among the young as well as the retired, whereas for the middle-aged, there is a tradeoff between work hours and retirement ages.

The current coincidence of the equity market meltdown coupled with the prospect of a long global recession underscores the reality that human and financial capital market shocks do occur simultaneously. For instance, Seligman and Wenger (2005) indicate that investment market returns tend to rise during periods of unemployment; to the extent that the stock market is a leading indicator, unemployed workers will miss an opportunity to invest via a pension when equity prices are low and rising. Such unemployment-related losses are larger for low-wage workers since they are more prone to job loss. Behavioral responses can also be important: for instance, Agnew (2004) finds that DC plan participants in the US have reacted to stock return declines by moving out of equities.

It has not yet been shown what particular format for a DC or DB pension might be better positioned to handle such complex risk interactions. Nevertheless, a few authors have "run the horserace" between plan types, seeking information on which might be superior across a range of financial and human capital risks. For instance, Blake et al. (2001) incorporate financial and wage volatility but fix hours and retirement ages; in this framework the authors focus on accumulations only, and compare only static and specific preset lifecycle asset allocation strategies. They conclude that using a static asset allocation model may be preferable to a VaR framework when there is uncertainty about the parameters and underlying model driving capital market returns. ${ }^{17}$ In another study, Hinz et al. (2001) ask whether human capital risks matter more for DC or DB pension outcomes in the US; their simulation model takes as input parameters on the timing of various life events such as first job start, first job finish, subsequent job starts and finishes, on-the-job promotions, disability, and death. The authors separately estimate hazard functions to predict waiting times between such events, using longitudinal datasets. The paper concludes that DB plans are riskier than DC plans in the U.S. context, due to the pension loss experience by job-changing workers. Their simulations report that DB benefits were 17 percent higher than DC plans on average, but the standard deviation of outcomes was 67 percent higher in DB plans, indicating substantially greater pension risk. Some workers fared better on average in DC plans (see Table 4). That study did not allow for correlations between labor market uncertainty and shocks to equity returns.

Table 4 here

Subsequent research by McCarthy (2003) also used a life cycle model of consumption and saving to compare DB versus DC plan outcomes, taking into account varying degrees of risk aversion and different wage processes correlated with returns on risky assets. That author found that DC plans provide

\footnotetext{
${ }^{17}$ This discussion is related to, but distinct from, the debate over whether a Value at Risk (VaR) approach often used by money managers is helpful in the DC context. In the DB context, a conditional Value at Risk (CVaR) model has been found to be quite useful in guiding investment decisionmaking; see Maurer et al. (2009b).
} 
better risk diversification for workers earlier in life because workers have few financial assets but relatively much human capital. By contrast, he found DB plans preferred later in life when they help reduce workers' exposure to financial markets. He also reported that DB plans would be more attractive to individuals with lower risk aversion. Table 5 illustrates the calculated sensitivity of the optimal DB replacement to human capital risk: the optimal replacement rate falls slightly as productivity growth increases, because the absolute benefit level rises. But wage variability has a large effect, with the optimal replacement rate rising substantially when wage variability is relatively low. This is because the benefits provided by final average pay DB plans are very sensitive to wage variability at the end of the working life. ${ }^{18}$

\section{Table 5 here}

In sum, a range of modeling techniques has been used for analyzing pension outcomes in the face of labor income uncertainty. The models differ as to how they deal with human capital risks and there remain ways to integrate labor income uncertainty into models of pension outcomes. Least well studied are the interactions with capital market shocks, and there is room for improvement in integrating both human and financial capital market shocks.

\section{Benchmarks for Pension Performance}

Before concluding our discussion of pension plan performance, it is important to briefly mention the wide range of benchmarks or concepts offered by which system outcomes have been judged (Mitchell 2008). Some authors project annual retirement benefits paid from a national social security or companybased defined benefit plan and compare these to a measure of national average wages (OECD 2007). Others convert annual retirement benefit flows into pension wealth, or the lifetime expected present value of promised pension benefits, as a way to determine a pension plan's generosity over the entire lifetime. In doing so, of course, the latter measure incorporates longevity into the pension performance value. For funded defined contribution systems, analysts compute projected account balances at retirement (e.g. Poterba et al. 2007). It is also conventional to use a "replacement rate" concept, or the ratio of pension payments compared to an income standard; the latter could refer to a worker's own final or career pay, or some national average pay level (e.g., Whitehouse 2007). The success of a pension system can alternatively be measured by the rate of return provided on invested assets. In what follows we briefly outline performance targets most employed in the policy and academic literature on benefit payouts.

\footnotetext{
${ }^{18}$ This discussion is related to, but distinct from, the debate over whether a Value at Risk (VaR) approach often used by money managers is useful in the DC context. For instance Blake et al. (2000) note that VaR results depend on the fund's asset allocation strategy; that model assumes fixed retirement ages and no annuities, as distinct from the models discussed above.
} 
Performance Target: Adequacy. One benchmark in wide use in the West compares benefits paid by a pension system (or are projected to be paid) to some minimum criterion, where the latter is usually a country's income-based poverty line, the minimum wage level, or a national average earnings measure. Adequacy metrics of this type have been used, for instance, by Citro and Michael (1995) who compare pension system income payments over time or across countries, usually for a hypothetical "average" or representative individual selected by the authors. This measure is useful in that it allows computation of how many people fall short of the minimum income line, and how large their shortfalls may be. On the other hand, some very interesting recent research by Meyer and Sullivan (2009) shows that income and consumption measures of deep poverty and poverty gaps in the US have actually moved in opposite directions over the past twenty years: income poverty rates have risen but consumption poverty has fallen. For this reason, it is necessary to carefully define what is meant by "adequacy" in attempting to judge whether a pension system is performing adequately.

Performance Target: Income Replacement Rate. A different and widely used concept for measuring pension system performance is the so-called income replacement rate. In the literature, a replacement rate refers to the amount of income a retiree receives from his pension compared to some active worker income level (OECD 2007, 2009). Target replacement rates of, say, 75 percent, are often recommended by financial planners for clients who cannot otherwise estimate what income they will need in retirement (Palmer 2004; VanDerhei 2006). ${ }^{19}$ A lower target replacement rate might be sensible if workers anticipate lower expenditures (and perhaps lower taxes) after leaving the labor market.

Implementing the replacement rate concept accordingly requires comparing two (more-or- less) readily observable economic flows, namely workers' market income and retirees' retirement benefits; pension systems would then be judged more successful when the replacement rate is higher. But despite the simplicity of this concept, in practice people come up with very different measures. For instance, analysts disagree about what period to cover with regard to the earnings in the numerator. Some compare pension benefits with a worker's own labor earnings immediately prior to retirement; others make the comparison with own preretirement pay in a few peak years; and still others compare retirement benefits to the worker's entire career average pay. ${ }^{20}$ (As an example, the U.S. Social Security system computes retirement benefits as a fraction of own pre-retirement earnings indexed for labor income growth; see

\footnotetext{
${ }^{19}$ Rates in the range of 70 to 80 percent are often proposed as sensible target replacement rates for retirement benefits in the US, with the caveat that low-income workers may require higher replacement rates since they consume a higher percentage of their pre-retirement income when working (Scholz and Seshadri 2008). The U.S. Department of Labor (2008) has recommended target replacement rates of at least 80 to 90 percent.

${ }^{20}$ For instance Biggs and Springstead (2008) use four different measures of pre-retirement earnings to compute alternative replacement rate measures: what they call "final" earnings (average real earnings in the five years preceding retirement), average lifetime wage-indexed earnings, average price-indexed earnings, and average real income computed based on the present value of real lifetime earnings. Of course, the average lifetime earnings measures ignore when the earnings are received.
} 
Bosworth et al. 1999). Also, analysts disagree on whether the replacement rate should compare benefits to gross (i.e. pretax) or net (after-tax) incomes (Munnell et al. 2006). A third issue is that benefits may be worth much more early in retirement than they are later, for instance, if benefit payments not inflationindexed. In such a case, what might appear to be an initially-generous replacement rate will be eroded over time. A fourth consideration is that focusing on retirement benefits overlooks how long benefits will be paid (e.g. for a term, or until death for the individual and his/her partner). A fifth issue is that replacement rates should, by rights, be adjusted for household composition; it is widely agreed that one person requires fewer resources than a couple and children residing in their families have distinct consumption needs (Hurd and Rohwedder, 2008). ${ }^{21}$ Additional complexities in measuring relative benefit generosity include that not all benefits are life annuities. Hence what might appear to be a generous benefit at one point in time might become less generous if, for instance, the retiree exhausts his resources due to overspending, poor planning, or other shocks (Brown et al. 2008). The point is that it is therefore critical to not only to assess replacement rate outcomes in a static sense, but also to track the trajectory of replacement rates over the retirement period to assess the risk of failure relative to some minimum target (VanDerhei 2006).

Other considerations regarding using benefit replacement rates as a criterion for pension plan performance include the possibility that retiree expenses might differ from those of younger persons. Thus nonworkers will not need to incur commuting costs and outlays for tools or clothing used on the job, or child-care expenses; in this case, daily expenses might be lower and so benefit income may stretch farther. On the other hand, some expenditures such as medical costs are substantially higher for retirees, and these costs tend to rise with age. Also, in the context of pension reform assessments, it is important to note that observed replacement rates will inevitably be endogenous. That is, the value of pension benefits paid is usually a function of when the worker retires, with the formula paying less to those who leave the job market early. In such a situation, an observed low replacement rate could either indicate a poorly performing system or the outcome of a program that permits workers to consume more leisure by leaving their jobs early. ${ }^{22}$ For this reason, it is useful to measure replacement rates for some simulated or

\footnotetext{
${ }^{21}$ It has been argued that the preferred way to compute replacement rate targets would not seek to maintain constant household consumption levels, but rather constant per capita consumption trajectories for those people remaining in the household. For instance Kotlikoff (2008) argues in favor of lower replacement rates than commonly used, noting that while raising children, adults with a typical family budget cannot consume very much. He calculates a target replacement rate of 42 percent for a couple with two children; the couple with no children has a target rate of 52 percent. Kotlikoff argues that conventional saving rate measures call for much higher saving than would be economically justified if the target were to smooth consumption per person over time.

${ }^{22}$ Also those desiring to retire earlier will need to have a higher saving rate to finance their longer years of retirement. This higher savings rate depresses their pre-retirement net income and hence consumption, which in turn reduces the level of consumption relative to income that they need to replace in retirement (Schieber 1998). Accordingly target replacement rates will be lower, the earlier is the target retirement age.
} 
hypothetical worker at given ages (e.g. the earliest age at which benefits can be received, the normal retirement age, etc.).

Dynamic Considerations. Where possible, policymakers seeking to assess pension outcomes must focus not simply on static benefit outcome projections, but also dynamic models that can include stochastic elements. To date, many authors have found ways to allow investment performance to be treated as stochastic, but as we explain in more detail below, one of the key factors determining pension outcomes is human capital risk. Few existing models do a very good job including this important stochastic factor driving pension outcomes.

Replacement Rates in Practice. In many policy settings, pension replacement rate computations are conducted using static projection models for representative or hypothetical individuals. Such an approach is most invaluable for actuarial models of benefit formulas and taxes, nicely exemplified in the Pension Reform Toolkit developed by the World Bank (World Bank 2008). This model has been used in over 80 countries to evaluate long-term flows of pension system revenues and expenditures, as well as to generate projected benefit amounts that can be used to compute replacement rate and adequacy measures. Similarly the OECD (2009) has produced several illustrative benefit computations for countries across the OECD, Africa, the Middle East, Eastern Europe, and Latin America. These replacement rates are measured as individual pension entitlements compared to individual earnings while working. The earnings measures use are the average of a hypothetical individual's lifetime earnings, where they revalue those earnings in line with the growth of average earnings in the economy. Whitehouse (2008) calculates both gross and net replacement rates, with net replacement rates subtracting out taxes on earnings and taxes on benefits.

An alternative approach computes replacement rates for actual rather than hypothetical workers. This is a data-intensive effort as it can only be implemented if a country has good longitudinal earnings histories for actual workers. Mitchell and Philips (2006) compare replacement rate measures estimated for hypothetical workers, with those computed using actual earnings data; they conclude that actual workers had many more gaps in their earnings than hypothetical workers. Since the U.S. pension system uses a progressive benefit formula, the results for actual workers generated higher replacement rates than would otherwise be concluded using hypothetical workers. ${ }^{23}$

A Caveat on Consumption Smoothing. A final point regarding pension outcomes measures is that replacement rates have been criticized by some as a poor measure of retirement wellbeing. The main reason is that the economic life cycle model of consumption and saving proposes that rational optimizing

\footnotetext{
${ }^{23}$ Using data from the U.S. Bureau of Labor Statistics' Consumer Expenditure Survey, the Aon/Georgia State RETIRE Project shows that low-earner couples have benefit replacement rates of 85 percent, middle-earner couples 75 percent, and high-income couples 78 percent (Palmer 2004).
} 
employees will seek to smooth the marginal utility of consumption over time, which is not equivalent to targeting a particular income replacement rate (Scholz et al. 2006). The point is that consumption patterns for many rationally change post-retirement, since their time is worth less in retirement than while working. As a result, retirees will naturally tend to substitute time for expenditure after leaving the job market - meaning that it is cheaper to live in retirement (Aguiar and Hurst 2005). As Skinner (2007) notes, "planning for consumption smoothing doesn't mean one has to maintain consumption spending through retirement."

Another consideration is that in-kind benefits are often not included in the metric of resources available to retirees, to some extent because it may be difficult to measure the value of food or transport subsidies, medical care provided, or the like. ${ }^{24}$ Such shortcomings in the computation of income replacement rates have led some to move away from the simple measure of income replacement rates toward measures that involve adjustments such as for the imputed rent on housing. Each of these points serves to weaken the theoretical underpinning for focusing on a simple retirement replacement rate goal.

Performance Target: Efficiency. An alternative indicator of pension performance could be the system's efficiency, again a concept that can be measured many different ways. One approach focuses on the level of fees and charges levied by the pension system (Mitchell 1998; Turner and Witte 2008). From this perspective, scale economies may arise due to fixed costs and also as a result of how the pension system is organized. For instance, when a defined contribution plan has a single pool of assets managed centrally, it may have lower administrative costs than the same plan with numerous individual accounts where each account holder is permitted to decide how his own assets are allocated. Economies also occur with experience, so that older plans may be more efficient than younger plans due to learning by doing. An alternative measure of efficiency is tied to the rates of return received on pension funds. For example, a defined contribution plan could charge low fees but be inefficient because of the lack of diversification provided by the offered investment menu (Tang and Mitchell 2008).

In sum, a commonly-used measure of pension system outcomes, namely benefit replacement rates, has been challenged for a number of theoretical and conceptual reasons. Nevertheless some analysts will still use an average target replacement rate of around 75 percent, but a more sophisticated approach is to emphasize instead adequacy targets, perhaps adjusted for household size and composition, benefits in kind, and taxes/transfers. Naturally, whatever metric is proposed, the challenge for policymakers interested in measuring outcomes is the reality that longitudinal microeconomic data that is needed to simulate, project, and assess lifetime labor income patterns and benefit outcomes.

\footnotetext{
${ }^{24}$ For instance, when a retiree owns his/her home, the flow of housing services received by the retiree should be computed as valuable consumption; some researchers therefore add into pre- and post-retirement income streams an imputed value for such housing services (Munnell et al. 2006).
} 


\section{Conclusions and Policy Implications}

This chapter emphasizes the key importance of integrating human capital and financial market risks into any assessment of pension system performance. The most relevant human capital risks discussed here include volatility of labor earnings, uncertainty in hours of work and the length of the worklife, and longevity in retirement. We have shown how such fluctuations in wage rates, unemployment, and hours of work can produce very different pension outcomes; and at the extensive margin, the length of the work and retirement periods also shape retirement payouts. In fact, the recent literature suggests that labor income uncertainty may be quantitatively more important than financial capital risk in determining retirement wellbeing for most people, insofar as their labor market earnings represent their primary form of wealth. We also show that the next generation of pension models will need to be more thoughtful in specifying what the sensible pension performance standards should be, moving beyond a simple income replacement rate notion to take into account consumption, leisure, and lifespans.

Analysis of pension outcomes and the impact of pension policy changes would be greatly facilitated by access to new microeconomic longitudinal data sources. Of most value would be information tracking individual workers over time, particularly panel data linked to administrative records. For example, the UK, US, and several European nations are now gathering such data which provide information on lifetime earnings as well as employment and pension contribution patterns, linked to socio-demographic detail about respondents. Similar efforts are now underway in Chile with the Social Protection Survey, Korea with the Korean Health and Retirement study, Japan with the Japanese Survey of Health and Retirement (JSTAR), and China with the CHARLS study. These datasets will be invaluable in providing a more realistic picture of the variability in labor earnings and employment patterns over the life cycle, patterns of contributions to pensions, and correlations between capital market and labor income patterns. It is also necessary to link these to 'metafiles' containing information on pension parameters as well as those of other related programs. For instance, if the goal is to model the range of benefit outcomes under a specific DB plan, the analyst must know the rules pertinent to job-changing or layoffs, vesting and backloading of benefit formulas, and the risk of DB plan closure due either to plan termination or sponsor bankruptcy. ${ }^{25}$ Similar parameters would be required for CDC plans, along with some forecast of benefit and contribution adjustments when times require them. Without the richness of micro-level data, it will be difficult to test and model distributional outcomes from pension plan performance. When such

\footnotetext{
${ }^{25}$ The US Pension Benefit Guaranty Corporation has devised a stochastic model known as the Pension Insurance Modeling System to assess how benefit claims evolve over time, taking into account demographic change, pension funding, and the chance of corporate bankruptcy. A short overview of this appears in PBGC (2008).
} 
detail is lacking, retirement analysts can use so-called "hypothetical workers," designed to describe the life cycle of 'representative' people of different types. Even here, it is important not to assume hypothetical profiles with full-time steady employment over a long career; otherwise one may overstate pension contributions, accumulations, and eventual retirement benefits (Pfau 2008). This is particularly important for modeling DC pension systems which could be anticipated to result in higher account balances than would actually apply to real-world workers.

In conclusion, recent research strongly indicates that both financial and human capital volatility must be taken into account when assessing pension performance metrics. In particularly, retirement investment strategies should make explicit the desired benefit or income replacement targets, and the modeling must take due account of variable wage and labor earnings patterns, variable patterns of labor force attachment, and unevenness in pension contribution rates. Furthermore these human capital aspects including work hours and retirement ages are plausibly highly correlated with financial market shocks, as the financial market crisis has made abundantly clear. 


\section{Bibliography}

Agnew, J. 2004. "An Analysis of How Individuals React to Market Returns in One 401(k) Plan." College of William and Mary.

Aguiar, M.and E. Hurst. 2005. "Consumption versus Expenditure," Journal of Political Economy, 113(5), October: 919-948.

Antolin, P. 2009. "Pension Fund Performance.” This volume.

Arenas de Mesa, A., D. Bravo, J. R. Behrman, O.S. Mitchell, and P.E. Todd. 2008. "The Chilean Pension Reform Turns 25: Lessons from the Social Protection Survey." In Lessons from Pension Reform in the Americas, Eds. S. Kay and T. Sinha. Oxford, Oxford University Press: 23-58.

Bagliano, F. C., C. Fugazza, and G. Nicodano. 2009. "Pension Funds, Life-Cycle Asset Allocation, and Pension Performance." This volume.

Bailey, C. and .A. Turner. 2001."Strategies to Reduce Contribution Evasion in Social Security Financing." World Development 29 (2001): 385-393

Baroni, E. and M. Richiardi. 2007. “Orcutt's Vision, 50 Years On.” Yale Economics Working Papers.

Bernal, N., A. Munoz, H. Perea, J. Tejada, and D.Tuesta. 2008. Una Mirada al Sistema Peruano de Pensiones. Lima, BBVA.

Berstein, S., G. Larraín, and F. Pino. 2005. "Cobertura, Densidad y Pensiones en Chile: Proyecciones a 20 años plazo". SAFP Documento de Trabajo N¹2, Santiago.

Biggs, A.G and G.R. Springstead. 2008. "Alternate Measures of Replacement Rates for Social Security Benefits and Retirement Income.” Social Security Bulletin, 68 No. 2, pp. 1-19.

Blake, D, A. Cairns and K. Dowd. 2007. "The Impact of Occupation and Gender on the Pensions from Defined Contribution Plans." Geneva Papers on Risk \& Insurance, 32, 458-82.

Blake, D., A. Cairns and K. Dowd. 2001. "PensionMetrics: Stochastic Pension Plan Design and Value at Risk during the Accumulation Phase." Insurance: Mathematics \& Economics, 29: 187-215

Bosch, M. and W.F. Maloney. 2006. "Gross Worker Flows in the Presence of Informal Labor Markets: The Mexican Experience- 1987-2002.” CEP Discussion Paper: Center for Economic Performance.

Bosworth, B., G. Burtless, and C. E. Steuerle. 2000. "Lifetime Earnings Patterns, the Distribution of Future Social Security Benefits, and the Impact of Pension Reform." Social Security Bulletin 63(4): 74-98.

Bovenberg, L. Nd. "The Dutch Collective Pension System: Best of both Worlds?” Netspar Working Papers, Tilberg University.

Brown, J. 2008. "Guaranteed Trouble: The Economic Effects of the Pension Benefit Guaranty Corporation.” The Journal of Economic Perspectives. 22(1): Winter.

Brown, J., J. King, S.Mulainathan, and M. V. Wrobel. 2008. "Why Don't the People Insure Late Life Consumption? A Framing Explanation of the Under-Annuitization Puzzle." TIAA-CREF Research Dialogue, April.

Bruce, E., J.A. Turner and D. Lee. 2005. "Lost Pensions: An Empirical Investigation.” Benefits Quarterly.

Bucheli, M., A.Forteza, and I. Rossi. 2007. "Work History and the Access to Contributory Pensions. The Case of Uruguay.” Departmento de Economía, Universidad de la República, Uruguay, Document no. 16/07, October.

Buessing, M. and M. Soto. 2006. "The State of Private Pensions: Current 5500 Data." Center for Retirement Research at Boston College, Issue Brief No. 42, February.

Burdick, C. and J. Manchester. 2003. "Stochastic Models of the Social Security Trust Funds." Research and Statistics Note 2003-01, Social Security Administration. 
Burtless, G. 2000. "How Would Financial Risk Affect Retirement Income Under Individual Accounts?" Center for Retirement Research at Boston College, Number 5, October.

Butrica, B.A., E.J Toder, and D. J. Toohey. 2008. "Boomers at the Bottom: How Will Low Income Boomers Cope with Retirement." AARP Public Policy Institute Research Report 2008-07.

Campbell, J.Y., J.F. Cocco, F.J. Gomes, and P.J. Maenhout. 1999. "Investing Retirement Wealth: A Life-Cycle Model." Harvard Institute of Economic Research Discussion Paper no. 1896, Cambridge, MA: Harvard University.

Chai, J., W. Horneff, R. Maurer, and O.S. Mitchell. 2009. "Extending Life Cycle Models of Optimal Portfolio Choice: Integrating Flexible Work, Endogenous Retirement, and Investment Decisions with Lifetime Payouts." NBER Working Paper.

Citro, C. F. and R. T. Michael (eds.). 1995. Measuring Poverty: A New Approach, Washington, D.C.: National Academy Press.

Cocco, J., F. Gomes, and P. Maenhout (2005). Consumption and Portfolio Choice over the Life Cycle. Review of Financial Studies 18, 491-533.

Cohen, B. and B. Fitzgerald. 2007. The Pension Puzzle $3^{\text {rd }}$ ed. Mississauga, Ontario: John Wiley \& Sons Canada, Ltd., 2007.

Congressional Budget Office (CBO). 2004a. "A Model to Project Flows into and Out of Tax-Deferred Retirement Saving Accounts." CBO Technical Paper 200415.

Congressional Budget Office (CBO). 2004b. "Tax-Deferred Retirement Saving." CBO Paper, May.

Crenner, E.. 2008. "Effects of the French Pension Reforms on Living Standards of Retirees: Intergenerational Comparisons." Presented at the Conference of the International Association of Research on Income and Wealth, Slovenia, August 24-28.

Curry, C. 1996. "PENSIM: A Dynamic Simulation Model of Pensioners' Income." Government Economic Service Working Paper No. 129. Analytical Services Division, Department of Social Security, London.

Dekkers, G., R. Desmet, S. Lefebure, G. Van Camp, K. Van den Bosch, and G. Verbist. 2009. "Comment Projeter l'Effet Distributif des Politiques Touchant les Pensions?: Comparaison des Modélisations Statique et Dynamique du Vieillissement." Association Internationale de Microsimulation. http://www.statcan.gc.ca/conferences/ima-aim2009/session2e-fra.htm

Dupont, G., C. Hagneré, and V. Touzé. 2003. "Les modèles de microsimulation dynamique dans l'analyse des réformes des systèmes de retraites une tentative de bilan." ("Dynamic Microsimulation Models Used to Analyze Retirement System Reforms: An Essay of Synthesis" (in French).

Favre, M., A. Melguizo, A. Muñoz and J. Vial. 2006. A 25 Años del la Reforma del Sistema Previsional Chileno: Evaluación y Propuestas de Ajuste. Santiago: BBVA.

Ferris, S. 2005. “Ansett's Superannuation Fund: A Case Study in Insolvency." In Hazel Bateman (ed.). Retirement Provision in Scary Markets, Edward Elgar, pp. 161-186.

Gomes, F., L. Kotlikoff, and L.M. Viceira. 2008. Optimal Life-Cycle Investing with Flexible Labor Supply: A Welfare Analysis of Life-Cycle Funds. American Economic Review: Papers \& Proceedings 98, 297-303.

Gruber, J., and D. A. Wise, eds. 2007. Social Security Programs and Retirement around the World: MicroEstimation. University of Chicago Press.

Gustman, A. and T. Steinmeier. 2002. "Retirement and the Stock Market Bubble." NBER Working Papers.

Hermes, Sharon. 2009. "Private Pension Reform and Personal Accounts in the UK: Implications for Women." Advances in Industrial and Labor Relations 16 (forthcoming).

Hinz, R. P., M.R. Holmer, and J.S. Piacentini. 2001. "The Accidental Pension: Miracle Cure or Retirement Roulette." Paper presented at the IZA Conference on Pension Reform and Labor Markets, Berlin, Germany, May 19. 
Holden, S. and J. VanDerhei. 2002a. "EBRI/ICI 401(k) Accumulation Projection Model and Appendix" Perspective. Investment Company Institute. vol. 8, no. 3a, November.

Holden, S. and J. VanDerhei. 2002b. "Can 401(k) Accumulations Generate Significant Income for Future Retirees?" Perspective. Investment Company Institute. vol. 8, no. 3, November.

Holmer, M. R. 2006. "PENSIM Analysis of Impact of Regulation on Defined-Contribution Default Investments." US Department of Labor Working Paper.

Horneff, W., R. Maurer, O.S. Mitchell, and I. Dus. 2007a. "Following the Rules: Integrating Asset Allocation and Annuitization in Retirement Portfolios. Insurance: Mathematics and Economics. 42: 2007: 396-408.

Horneff, W. R. Maurer, O.S. Mitchell and MZ. Stamos. 2009. "Asset Allocation and Location over the Life Cycle with Investment-Linked Survival-Contingent Payouts." Journal of Banking and Finance (forthcoming).

Horneff, W., R. Maurer, O.S. Mitchell, and I. Dus. 2007 "Following the Rules: Integrating Asset Allocation and Annuitization in Retirement Portfolios. Insurance: Mathematics and Economics. 42: 396-408.

Hurd, M.D. and S. Rohwedder. 2008. "Adequacy of Economic Resources in Retirement and Returns-to-Scale in Retirement.” Michigan Retirement Research Center Working Paper 2008-174, May.

Kotlikoff, L. J. 2008. "The Economics Approach to Financial Planning." Journal of Financial Planning March, pp $40-48$.

Laise, E. 2009. "Odds-On Imperfection: Monte Carlo Simulation. Financial-Planning Tool Fails to Gauge Extreme Events." Wall Street Journal, May 2.

LeBlanc, P. 2002. "RRSPs and Pre-Retirement Earnings Replacement." Chapter in PhD Dissertation entitled "Essays on Tax-Deferred Savings in Canada." Harvard University.

Maurer, R., O.S. Mitchell, and R. Rogalla. 2009a. "The Effect of Uncertain Labor Income and Social Security on Lifecycle Portfolios.” Pension Research Council Working Paper.

Maurer, R., O.S. Mitchell, and R. Rogalla. 2009b. "Managing Contribution and Capital Market Risk in a Funded Public Defined Benefit Plan: Impact of CVaR Cost Constraints." Insurance: Mathematics \& Economics. (45): 25-34.

Maurer, R., and C. Schlag. 2003. "Money-Back Guarantees in Individual Pension Accounts: Evidence from the German Pension Reform." In The Pension Challenge: Risk Transfers and Retirement Income Security. Eds OS. Mitchell and K. Smetters, Editors. Oxford: Oxford University Press. 187-213.

Mazumder, B. 2001. "The Mismeasurement of Permanent Earnings: New Evidence from Social Security Earnings Data." Federal Reserve Bank of Chicago Working Paper 2001-24.

McCarthy, D. 2003. “A Life-Cycle Analysis of Defined Benefit Pension Plans." Journal of Pensions Economics and Finance 2 (2): 99-126, July.

McGill, D, K., Brown, J. Haley, S. Schieber, and M. Warshawsky. 2009. Fundamentals of Private Pensions. $9^{\text {th }}$ ed. Oxford University Press.

Meyer, B. D., and J. X. Sullivan. 2009. Five Decades of Consumption and Income Poverty. NBER Working Paper 14827. March.

Mitchell, O.S. 1998. "Administrative Costs of Public and Private Pension Plans". In Privatizing Social Security, ed. M. Feldstein. NBER. Chicago: University of Chicago Press: 403-456.

Mitchell, O.S. 2008. "New Directions for Pension System Performance Measurement." Presented at the International Seminar on "Pensions for the Future: Developing Individually Funded Programs" held by the International Federation of Pension Fund Administrators (FIAP) and the Peruvian Association of Private Pension Fund Administrators. Lima, Peru.

Mitchell, O.S., J. Moore, and J. Phillips. 2000. "Explaining Retirement Saving Shortfalls". In Forecasting Retirement Needs and Retirement Wealth. Eds. O.S. Mitchell, B. Hammond, and A. Rappaport. Philadelphia, PA: University of Pennsylvania Press: 139-166. 
Mitchell, O.S. and J. Phillips. 2006. "Social Security Replacement Rates for Alternative Earnings Benchmarks." Benefits Quarterly, Fourth Quarter: 37-47.

Mitchell, O.S., J. Phillips, and A. Au. 2007. "Lifetime Earnings Variability and Retirement Shortfalls." In Retirement Provision in Scary Markets. Ed. H. Bateman. Cheltenham, UK: Edward Elgar: 78-99.

Munnell, A., A. Webb and L. Delorme. 2006. "Retirements at Risk: A New National Retirement Risk Index." Center for Retirement Research at Boston College, June.

Musalem, A. and R. Pasquini. 2009. "Private Pension Systems: Cross-Country Investment Performance." This volume.

Neumann, J.. 2008. “Argentina Nationalizes Pension Funds; Analysts Say a Mixed bag." Star Tribune, November 20. www.startribune.com/business/34837309.html

Nichols, A. and M.M. Favreault. 2008. "The Impact of Changing Earnings Volatility on Retirement Wealth." Presented at the 10th Annual Joint Conference of the Retirement Research Consortium. August 7-8, Washington, D.C

O’Connor-Grant, C.. 2008. "Putnam Finds Diminishing 401(k) Contributions.” OnWallStreet.com, June 23.

OECD. 2008. Pension Markets in Focus. OECD, Paris.

OECD. 2007. Pensions at a Glance: Public Policies Across OECD Countries. OECD, Paris.

OECD. 2009. Pensions at a Glance: Retirement Income Systems in OECD Countries. OECD, Paris.

Orcutt, G.H. 1957. “A New Type of Socio Economic System.” Review of Economics and Statistics, 58: 773-797.

Palmer, B.A. 2004. 2004 GSU/Aon RETIRE Project Report. Atlanta, Georgia: Center for Risk Management and Insurance Research at Georgia State University.

Pension Benefit Guaranty Corporation (PBGC). 2008. Annual Report. http://www.pbgc.org/docs/2008 annual_report.pdf

Pfau, W. D. 2008. "Assessing the Applicability of Hypothetical Workers for Defined-Contribution Pensions." National Graduate Institute for Policy Studies, Tokyo, Japan, GRIPS Policy Information Center Discussion Paper no. 07-11.

Poterba, J, S. Venti and D.A, Wise. 2007. "New Estimates of the Future Path of 401(k) Assets." NBER Working Paper no. 13083, May.

Sabelhaus, J. 2008. CBOLT Documentation. Background Paper. Washington, D.C.: Congressional Budget Office.

Sabelhaus, J. and P. Brady. 2008. "The Role of Defined Contribution Accounts in Future Retirement Income Security: A Dynamic Microsimulation Approach.” Investment Company Institute, May.

Sarney, M. 2008. "Distributional Effects of Increasing the Benefit Computation Period." Policy Brief No. 200802. Social Security Administration, Office of Policy.

Schieber, S.J. 1998. Deriving Pretreatment Income Replacement Rates and the Savings Rates Needed to Meet Them. Benefits Quarterly 14(2): 53-69.

Scholz, J.K. and A. Seshadri. 2008. “Are All Americans Saving 'Optimally' for Retirement?” Presented at the 10th Annual Joint Conference of the Retirement Research Consortium. August 7-8, Washington, D.C.

Scholz, J.K., A. Seshadri, and S. Khitatrakun. 2006. “Are Americans Saving 'Optimally' for Retirement?” Journal of Political Economy 116 (2006): 607-643.

Seligman, J.S. and J.B. Wenger. 2005. "Asynchronous Risk, Unemployment, Equity Markets, and Retirement Savings.” Upjohn Institute Working Paper no. 05-114.

Skinner, J. 2007. “Are You Sure You Are Saving Enough for Retirement? NBER Working Paper 12981.

Smith, K., R. Johnson, and L. Muller. 2004. "Deferring Income in Employer-sponsored Retirement Plans: The Dynamics of Participant Contributions." National Tax Journal LV11 (3). 
Smith, P. 2001. "A Longer Term Perspective on IRA Participation: Evidence from a Panel of Tax Returns." US Office of Tax Analysis, Department of Treasury.

Smith, S. 2006. "The Persistency of Pension Contributions in the U.K.: Evidence from Aggregate and Micro Data." CIMPO, The University of Bristol, U.K., January. www.bris.ac.uk/Depts/CMPO/workingpapers/wp139.pdf

Soares, C. and M. Warshawsky. 2002. "Annuity Risk: Volatility and Inflation Exposure in Payments from Immediate Life Annuities." Presented at the Center for Research in Pension and Welfare Policies, Conference on "Developing an Annuity Market in Europe." Turin.

Tang, N. and O.S. Mitchell. 2008. "The Efficiency of Pension Plan Investment Menus: Investment Choices in Defined Contribution Pension Plans." Pension Research Council Working Paper No. WP2008-02, June.

Turner, J.A. and D.M. Rajnes. 2003. "Rate of Return Guarantees for Voluntary Defined Contribution Plans." Risk Transfers and Retirement Income Security, edited by Olivia S. Mitchell and Kent Smetters, Oxford University Press: 251- 267.

Turner, J.A. and H.A. Witte. 2008. "Fee Disclosure to Pension Participants: Establishing Minimum Requirements." Report to the International Centre for Pension Management (ICPM) at the University of Toronto.

U.S. Department of Labor, Employee Benefits Security Administration. 2008. "Taking the Mystery Out of Retirement Planning."

VanDerhei, J. 2006. "Measuring Retirement Income Adequacy: Calculating Realistic Income Replacement Rates." EBRI Issue Brief, No. 297, September.

van Rooij, M, A. Siegmann, and P. Vlaar. 2005. "PALMNET: A Pension Asset and Liability Model for the Netherlands." DNB Research Memorandum WO No. 760, February.

Viceira, L. 2009. "Pension Fund Design in Developing Economies." This volume.

Walker, E. and A. Iglesias. 2009. "Financial Performance of Pension Fund Systems Around the World: An Exploratory Study." This volume.

Wesbroom, K. and T. Reay. 2005. "Hybrid Pension Plans: UK and International Experience.” U.K. Department for Work and Pensions, Research Report 271.

Whitehouse, E. 2007. Pensions Panorama: Retirement Income Systems in 53 Countries. Washington, DC: The World Bank.

World Bank. 2008. "Modeling Pension Reform: The World Bank’s Pension Reform Options Simulation Toolkit." 
Table 1. How Human Capital Risks Translate into Pension Outcomes: A Framework

\section{Pension Plan Type}

\begin{tabular}{llll} 
& Defined & Collective Defined & Defined \\
Risk: & Benefit (DB) & Contribution (CDC) & Contribution (DC) \\
\hline
\end{tabular}

I. Employee-side Labor Income Shock

- Skill obsolescence Partly smoothed

- Health shock (depends on benefit

- Disability shock formula)

- Labor force exit

- Death
Benefit not bequeathed;

survivor benefit possible
Like DB

Contributions

directly affected

Accumulation may be bequeathed

II. Employer-side Employment Shock

- Hours Reduction

- Layoff/Firing

- Retirement
Accrual halted; Like DB nonvested benefit lost and final benefit may be very low
Accrual protected; assets keep earning investment returns

Source: Authors' compilation. 
Table 2. Life-Cycle Earnings Profiles Reported in US Micro Data

Life-Cycle

Earnings Profile

Low

Hump-Shaped $(\%)$

Men

Women

$\underline{\text { Rising }(\%)}$

Men

Women

Declining $(\%)$

Men $\quad 10.2$

Women
0.5

4.6

$3 . .8$

24.1

25.0
Earnings Level

Average $\quad \underline{\text { High }}$

3.4

5.4

24.1

2.5

10.1

6.2

21.8

18.8

24.9

9.0

1.4

Source: Derived from Bosworth et al. (1999). 
Table 3. Examples of Pension Modeling Approaches

\begin{tabular}{|c|c|c|c|c|c|c|}
\hline Model/ country & $\begin{array}{c}\text { Data/ } \\
\text { parameter } \\
\text { inputs }\end{array}$ & $\begin{array}{c}\text { Outputs/ } \\
\text { results }\end{array}$ & $\begin{array}{l}\text { Pension } \\
\text { framework }\end{array}$ & $\begin{array}{c}\text { Solution } \\
\text { methodology }\end{array}$ & $\begin{array}{l}\text { Risk } \\
\text { framework }\end{array}$ & $\begin{array}{l}\text { Macro feedback } \\
\text { links }\end{array}$ \\
\hline \multicolumn{7}{|c|}{ I. Aggregate Projection Model } \\
\hline $\begin{array}{l}\text { World Bank (2008) } \\
\text { Prost }\end{array}$ & $\begin{array}{l}\text { Est, Proj, } \\
\text { Agg, NA }\end{array}$ & $\begin{array}{l}\text { Pens, Fund, } \\
\text { Ben }\end{array}$ & SS & $\begin{array}{l}\text { Det, Indiv, } \\
\quad \text { agg }\end{array}$ & NR & None \\
\hline \multicolumn{7}{|c|}{$\begin{array}{l}\text { II. Micro Projection/description Model } \\
\text { 1. Deterministic }\end{array}$} \\
\hline $\begin{array}{l}\text { Bosworth et al. } \\
\text { (1999) US }\end{array}$ & $\begin{array}{l}\text { MSim, Hypo, } \\
\text { NA }\end{array}$ & RRi & SS & Det, Indiv & NR & None \\
\hline $\begin{array}{l}\text { Poterba et al. (2007) } \\
\text { US }\end{array}$ & NU, NA & Adeq & $\mathrm{DC}$ & Det, Indiv & NR & None \\
\hline $\begin{array}{l}\text { Munnell et al. } \\
\text { (2006) US } \\
\text { 2. Stochastic }\end{array}$ & NU, NA & RRi & $\begin{array}{c}\mathrm{DB}, \mathrm{DC} \\
\mathrm{SS}\end{array}$ & Det, Indiv & NR & None \\
\hline $\begin{array}{l}\text { Scholz et al. (2008) } \\
\text { US }\end{array}$ & $\begin{array}{l}\text { MSim, Long, } \\
\text { Est }\end{array}$ & Wealth & $\begin{array}{l}\mathrm{DB}, \mathrm{DC} \\
\quad \mathrm{SS}\end{array}$ & Opt, Indiv & $\begin{array}{l}\text { v, Mort, } \\
\text { health }\end{array}$ & None \\
\hline $\begin{array}{l}\text { van Rooij et al. } \\
\text { (2005) Netherlands }\end{array}$ & Agg, Est, NA & Fund & DB & Monte. Agg & $\mathrm{R}$, bond, infl & None \\
\hline $\begin{array}{l}\text { Hinz et al. (2001) } \\
\text { Pensim US }\end{array}$ & MSim, NA & Pens. Ben & $\begin{array}{c}\mathrm{DB}, \mathrm{DC} \\
\mathrm{SS}\end{array}$ & Msim, Indiv & $\begin{array}{l}\text { v, r. bond, } \\
\text { infl, Mort, } \\
\text { health }\end{array}$ & None \\
\hline \multicolumn{7}{|c|}{ III. Micro Optimization } \\
\hline $\begin{array}{l}\text { Horneff et al. (2009) } \\
\text { US }\end{array}$ & MSim. RA, r & Inv & $\mathrm{NU}$ & $\begin{array}{l}\text { Opt, Monte, } \\
\text { Indiv }\end{array}$ & $\begin{array}{l}\text { v, r. Mort, } \\
\text { health, house }\end{array}$ & None \\
\hline Kotlikoff (2008) US & Proj, NA & Consum & $\begin{array}{l}\mathrm{DB}, \mathrm{DC} \\
\quad \mathrm{SS}\end{array}$ & $\begin{array}{l}\text { Opt, DP, } \\
\text { Indiv }\end{array}$ & NR & None \\
\hline $\begin{array}{l}\text { Hurd and } \\
\text { Rohwedder (2008) } \\
\text { US }\end{array}$ & NU & Consum & NU & Sim, Indiv & Mort & None \\
\hline
\end{tabular}

Source: Authors' compilation; see text.

Key:

Data/Parameter Inputs:

Labor Earnings: Long= Longitudinal Earnings; Est = estimated, Hypo = hypothetical; MSim = microsimulation; Proj = projections, Agg = aggregate; $\mathrm{NU}=$ not used in model

Outputs/results:

Utility function: $\mathrm{NA}=$ none, $\mathrm{RA}=$ risk aversion, $\mathrm{r}=$ time preference

$\mathrm{RRi}=$ replacement rate for individual(s); RRg = replacement rates for a group of people; Adeq = adequacy measure; Wealth $=$ wealth target, Cons $=$ consumption target, Inv $=$ investment allocation; Pens $=$ pension assets; funding $=$ funding ratio, Ben $=$ benefit level

Pension framework:

$\mathrm{DB}=$ defined benefit, $\mathrm{DC}=$ defined contribution, $\mathrm{H}=$ hybrid, $\mathrm{SS}=$ social security, $\mathrm{NU}=$ not used

Solution framework:

Det = deterministic; Stoch = stochastic; $\mathrm{Sim}=$ simulation; Opt = optimization; Monte $=$ Monte Carlo; DP =

\section{Risk framework:} dynamic programming; Indiv= individual; $\mathrm{Coh}=$ cohort; Agg = aggregate;

$\mathrm{NR}=$ no risk included

K market: Irf = Risk-free interest rate; $\mathrm{r}=$ Equity return; $\mathrm{B}=$ bond return; Infl = inflation risk; house = housing expenses

Human capital: $\mathrm{v}=$ earnings volatility (including due to unemployment); Mort = longevity risk; Health= health and disability risk; Behav = behavioral risk

Institutional: Bank = bankruptcy risk;

Political risk: Polit = political risk (e.g. tax law changes)

Correlation: $\sigma=$ vector of correlations between capital market, human capital, institutional and political risk

Macro links: No feedback loops between macroeconomy and micro models. 
Table 4. Simulated Difference between a DC Account Balance and a DB Lump Sum Amount: Age 65 Retirees arrayed by Tenure Quintile (on Longest Job) and Lifetime Earnings Quintile

\begin{tabular}{ccc} 
Quintile & \multicolumn{2}{c}{ Percentage difference between DC lump sum balance and } \\
\cline { 2 - 3 } & \multicolumn{2}{c}{ DB Plan lump sum value at retirement } \\
& By Job Tenure Quintile & By Lifetime Earnings \\
1 & $(\%)$ & Quintile (\%) \\
2 & 4 & 2 \\
3 & -2 & 3 \\
4 & -6 & -2 \\
5 & -8 & -24
\end{tabular}

Source: Derived from Hinz et al. (2001). Note: Values approximate.

Table 5. Sensitivity of Optimal DB Pension Replacement Rate to Human Capital Risk

Sensitivity to human capital risk

Earnings Growth (\% per year) Optimal DB replacement ratio (\%)

$\begin{array}{lr}0 & 28 \\ 1 & 26 \\ 2 & 24 \\ \text { ity factor } & \\ 0.5 & 56 \\ 1.0 & 28 \\ 1.5 & 3\end{array}$

Source: Derived from McCarthy (2003). Note: Wage variability refers to a factor by which the temporary and permanent components of wage variability are multiplied to illustrate the effect of variation in wages. Base value is 1.0 . 
Figure 1. Patterns of Lifetime Earnings over the Lifetime, with Wage Level Indicator:

Excluding and Including Zero Earners

Average earnings as a percent of economy-wide average earnings on left scale; percent of category with zero earnings in each year measured on right scale. Solid line refers to all workers including unemployed; dashed line refers to workers with positive earnings; and dotted line refers to percent of workers with zero earnings by age. Source: Derived from Bosworth et al. (2000).

Panel A. Low Income Workers with Rising Life Cycle Earnings: With and Without Zero Earners

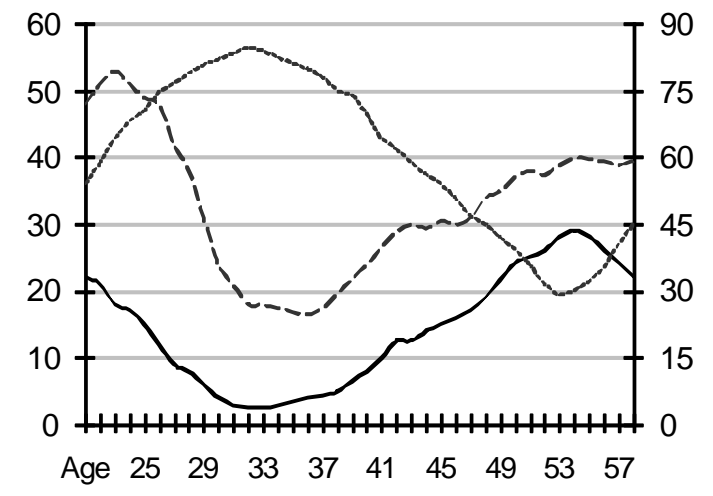

Panel B. Middle Income Workers with Rising Life Cycle Earnings: With and Without Zero Earners

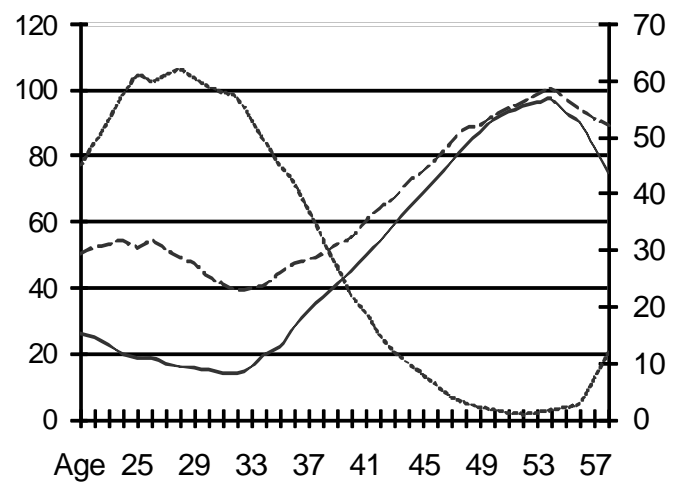

Panel C. High Income Workers with Rising Life Cycle Earnings: With and Without Zero Earners

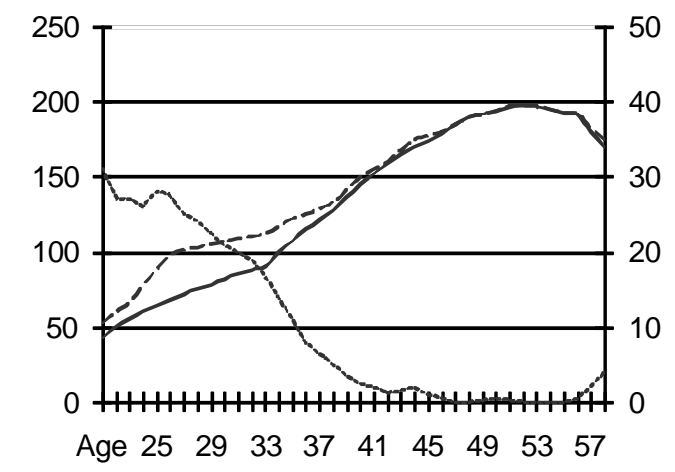


Figure 2. Pension Contribution Patterns in Chile by Age:

Percent of Available Years in Which Contributions Were Made

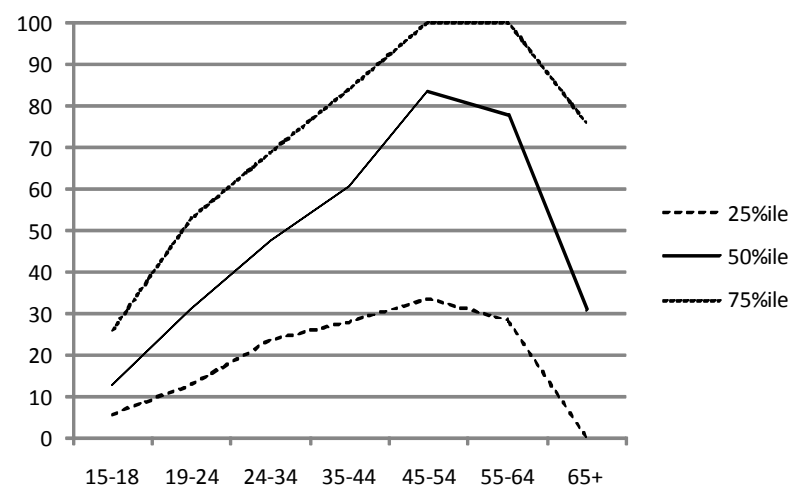

Source: Arenas et al. (2008) 